\title{
The experience of West Nile virus integrated surveillance system in the Emilia-Romagna region: five years of implementation, Italy, 2009 to 2013
}

R Bellini (rbellini@caa.it) ${ }^{1}$, M Calzolari ${ }^{2}$, A Mattivi $^{3}$, M Tamba $^{2}$, P Angelini ${ }^{3}$, P Bonilauri ${ }^{2}$, A Albieri ${ }^{1}$, R Cagarelli $^{3}$, M Carrieri $^{1}$,

M Dottori ${ }^{2}$, A C Finarelli ${ }^{3}$, P Gaibani ${ }^{4}$, M P Landini 4 , S Natalini ${ }^{3}$, N Pascarelli ${ }^{5}$, G Rossini ${ }^{4}$, C Velati ${ }^{6}$, C Vocale $^{4}$, E Bedeschi ${ }^{3}$

1. Centro Agricoltura Ambiente "G.Nicoli", Crevalcore, Italy

2. Istituto Zooprofilattico Sperimentale della Lombardia e dell’Emilia Romagna “B. Ubertini” (IZSLER), Brescia, Italy

3. General Direction for Health and Social Policies, Regione Emilia-Romagna, Bologna, Italy

4. Regional Reference Centre for Microbiological Emergencies (CRREM), Microbiology Unit, Azienda Ospedaliero-Universitaria di Bologna, Policlinico S.Orsola-Malpighi, Bologna, Italy

5. Blood Donors Biological Qualification Unit, AUSL of Bologna, Bologna, Italy

6. Regional Blood Centre, Regione Emilia-Romagna, Bologna, Italy

Bellini R, Calzolari M, Mattivi A, Tamba M, Angelini P, Bonilauri P, Albieri A, Cagarelli R, Carrieri M, Dottori M, Finarelli AC, Gaibani P, Landini MP, Natalini S,

Pascarelli N, Rossini G, Velati C, Vocale C, Bedeschi E. The experience of West Nile virus integrated surveillance system in the Emilia-Romagna region: five years of implementation, Italy, 2009 to 2013. Euro Surveill. 2014;19(44):pii=20953. Available online: http://www.eurosurveillance.org/ViewArticle.aspx?Articleld=20953

Article submitted on 23 April 2014 / published on 06 November 2014

Predicting West Nile virus (WNV) circulation and the risk of WNV epidemics is difficult due to complex interactions of multiple factors involved. Surveillance systems that timely detect virus activity in targeted areas, and allow evidence-based risk assessments may therefore be necessary. Since 2009, a system integrating environmental (mosquitoes and birds) and human surveillance has been implemented and progressively improved in the Emilia-Romagna region, Italy. The objective is to increase knowledge of WNV circulation and to reduce the probability of virus transmission via blood, tissue and organ donation. As of 2013, the system has shown highly satisfactory results in terms of early detection capacity (the environmental surveillance component allowed detection of WNV circulation 3-4 weeks before human cases of West Nile neuroinvasive disease (WNND) occurred), sensitivity (capacity to detect virus circulation even at the enzootic level) and area specificity (capacity to indicate the spatial distribution of the risk for WNND). Strong correlations were observed between the vector index values and the number of human WNND cases registered at the province level. Taking into consideration two scenarios of surveillance, the first with environmental surveillance and the second without, the total costs for the period from 2009 to 2013 were reduced when environmental surveillance was considered (EUR 2.093 million for the first scenario vs EUR 2.560 million for the second). Environmental surveillance helped to reduce costs by enabling a more targeted blood unit testing strategy. The inclusion of environmental surveillance also increased the efficiency of detecting infected blood units and further allowed evidence-based adoption of preventative public health measures.

\section{Introduction}

West Nile virus (WNV) is a worldwide-distributed mosquito-transmitted flavivirus causing growing concern in Europe because of its ability to induce neuroinvasive disease (WNND) in humans [1]. In addition to the risk of vector-borne transmission, the high proportion of asymptomatic persons with the virus relative to those presenting with WNND, estimated at more than 100:1, poses a risk of WNV transmission via blood transfusion or organ transplantation [2].

WNV is maintained in the environment primarily by wild birds, in an enzootic cycle involving both migrating and residential species [3]. The virus may disappear or remain undetected for long periods, but during hot seasons and in places with suitable ecological conditions, the virus circulation may increase to affect humans and equids [3]. In Europe, based on the evidence to date, both the amplifying and the bridge vector roles are covered by Culex pipiens sensu lato (s.l.) [4-6], with $C x$. modestus playing a bridge role in specific areas [7]. Generally, in temperate regions, it has been shown that the virus may overwinter in infected female mosquitoes as well as in residential birds, so there is no need for continuous re-introductions by migrating birds [8-11].

Although WNV circulation has been observed in several European Union (EU) Member States since the early 1950s, large WNV outbreaks have only been documented starting from the mid-1990s. The largest WNV outbreak in the EU, with over 390 confirmed cases, was reported in Romania in 1996 [4]. Greece experienced the second largest outbreak with 197 human cases in 2010 [12]. Sporadic human cases as well as outbreaks of various sizes have been reported 
in Albania, Austria, Bosnia and Herzegovina, Bulgaria, Croatia, Czech Republic, the former Yugoslav Republic of Macedonia, Greece, Hungary, Italy, Kosovo under United Nation Security Council Resolution 1244, Montenegro, Romania, Russia, Serbia, Slovenia, Spain and Ukraine [13].

In Italy cases of WNV infection have been registered regularly since 2011 (with 69 in 2013, 50 in 2012 and 14 in 2011) and have been distributed in several regions, including the Emilia-Romagna region. Cases occur mostly in the summer and autumn following an annual seasonal pattern. To prevent WNV transmission by blood transfusion and organ donation a national surveillance plan has been in place since 2008. According to the last issue of this plan, screening of blood units and organs is performed between 1 July and 30 November in provinces where humans or equids infected with WNV have been registered in the previous season. For other provinces, blood unit and organ screening are initiated in the current season a week after the detection of an equine case of WNV infection or a human WNND case.
The prevention and control of WNV is complex and requires the implementation of a comprehensive surveillance system $[14,15]$. Environmental surveillance, based on mosquito and/or bird collection and subsequent screening for the pathogen, has been shown to perform well in detecting the virus circulation well before the occurrence of human cases in addition to allowing size estimations of human outbreaks of WNV and identification of affected areas [16-19]. Since 2009, an integrated surveillance targeting mosquitoes, birds, and humans, has been put into effect in the EmiliaRomagna region, northern Italy. The main goals of this regional WNV surveillance are to contain the spread of WNV infections in humans and to more effectively reduce the probability of virus transmission via blood, tissue and organ donation systems. The surveillance system, which was originally described by Angelini et al. [20] and Calzolari et al. [21], has undergone further adaptations over time.

In this report, we present the development of the surveillance plan in the five years following its first implementation. We also present a cost comparison between two scenarios for preventing WNV transmission by transfusion and/or organ transplantation: scenario $A$,

\section{FIGURE 1}

Distribution of mosquito collection stations in the target area for West Nile virus entomological surveillance, Emilia-Romagna region, Italy, 2013

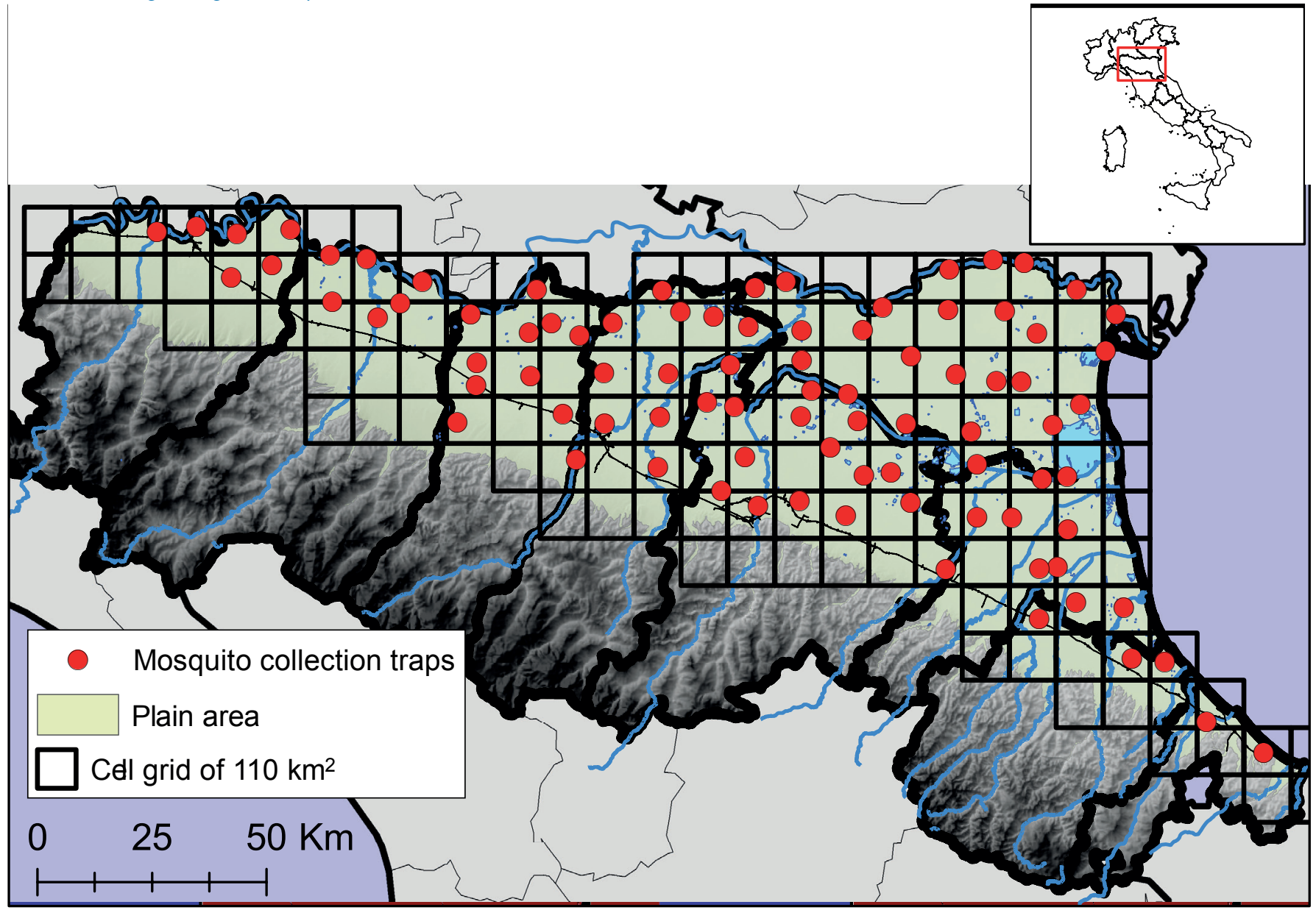


which follows the WNV Italian national plan and scenario $B$, which is based on evidence from a surveillance integrating environmental observations. In scenario $B$, blood unit and organ screening within a season is initiated at the province level when the mosquito or the bird active surveillance show WNV circulation in this province. Should a WNND human case occur before the detection of WNV circulation by the entomological or ornithological surveillance in the province, the measures to be taken are as in the national surveillance plan for this particular situation.

\section{Methods}

\section{Area under surveillance}

The Emilia-Romagna region has a total surface area of ca $22,450 \mathrm{~km}^{2}$ with a population of 4.47 million. The area under surveillance is ca $11,000 \mathrm{~km}^{2}$ and is located in the Po valley plain, where more than $90 \%$ of the region's residents live, and where ecological conditions (such as $C X$. pipiens breeding sites density and distribution, bird species population and environmental parameters) are considered suitable to WNV circulation.

\section{Entomological surveillance}

Following the detection of human cases of WNV infection in 2008 in the Emilia-Romagna region, a surveillance network was designed and operated in the summer period (June-October) [19-22]. In the 2009 season, mosquito collections were conducted partially in fixed stations and partially in occasional stations, with weekly to monthly periodicity. From the 2010 season the mosquito collections were standardised in fixed geo-referenced stations with fortnightly periodicity. Female mosquitoes were trapped using $\mathrm{CO}_{2}$ baited traps (and gravid traps from 2012), activated one night per collection. The network was initially designed to cover the regional plain area using a grid with cells of ca $110 \mathrm{~km}^{2}$ (Figure). The specific location of the station in each cell was chosen by skilled entomologists to optimise Culex collections. The surveillance plan was conducted regularly with slight modifications during the five years.

Collected mosquitoes were counted, identified at the species level and pooled according to date, location, and species, with a maximum number of 200 individuals per pool. In case of large collections a maximum number of 1,000 mosquitoes/trap/night/species (equals to 5 pools of 200) was submitted to the laboratory for analysis, while the remaining mosquitoes were determined to the species level and discharged. Pooled mosquitoes were stored in polypropylene cryotubes and frozen at $-80^{\circ} \mathrm{C}$. For biomolecular analysis, samples were first ground by adding copper-plated round balls, phosphate buffer saline solution and vortexing, and then were subsequently centrifuged. To optimise costs of analysis, aliquots of small pools of mosquitoes (below 30 individuals) were combined with a super-pool approach [4].
Ornithological surveillance

According to the WNV national surveillance plan, an active surveillance was started since 2006 on corvid species, which are considered as agricultural pests and therefore the target of population control programmes. These include: Eurasian magpies (Pica pica), hooded crows (Corvus cornix), carrion crows (Corvus corone) and Eurasian jays (Garrulus glandarius). Birds were trapped in the plain and low hill areas (up to $600 \mathrm{~m}$ above sea level (a.s.l.)) in eight (Bologna, Ferrara, ForliCesena, Modena, Parma, Piacenza, Ravenna, Reggio Emilia) of the nine provinces of the region. The culling programme was performed from May to October, dividing the surveyed area into quadrants sized $1,600 \mathrm{~km}^{2}$ and collecting 15 to 20 specimens in each quadrant every month.

Birds' organ samples (brain, spleen, heart, and kidney) were pooled, ground, and submitted for biomolecular analysis. Samples from every bird were processed individually.

\section{Human surveillance}

The human surveillance system was based on the active identification of WNND human cases in a period defined every year by national guidelines (see results). According to the national case definition, every subject presenting fever $\left(\geq 38.5^{\circ} \mathrm{C}\right)$ and a neurologic manifestation such as acute flaccid paralysis, acute polyradiculoneuritis (Guillain-Barré syndrome), aseptic meningitis, or encephalitis was considered as a suspect case and therefore laboratory investigated.

Every suspect case was promptly reported to the Public Health Department and biological samples were transmitted to the Regional Reference Centre for Microbiological Emergency (CRREM) within the Unit of Clinical Microbiology of the St. Orsola University Hospital, Bologna. According to laboratory findings, the suspected cases were classified as confirmed cases following national guidelines (http://www.trovanorme. salute.gov.it/norme/dettaglioAtto?id=49423).

\section{Blood donation system}

The national strategy for prevention of WNV transmission by transfusion indicates that, in regions where no virus circulation was observed in the previous year, like was the case for the Emilia-Romagna in 2013, only blood donors with a minimum overnight stay in affected areas (defined at the province level) are to be tested for WNV RNA. Moreover a WNV RNA screening of all blood units in a given province shall start in a week following the first WNND human or equine WNV infection case detection.

In 2013, the integrated regional surveillance system requires that WNV nucleic acid testing (NAT) screening is applied to all blood donors in a province after reports of at least two positive mosquito pools by the entomological surveillance network, or one positive bird, within the limits of the province without waiting 
Main parameters and outputs of the surveillance activities, Emilia-Romagna region, Italy, 2009-2013

\begin{tabular}{|c|c|c|c|c|c|c|c|}
\hline Year & $\begin{array}{c}\text { Traps } \\
(n)^{\mathrm{a}}\end{array}$ & $\begin{array}{c}\text { Area around the } \\
\text { trap } \\
\left(\mathrm{km}^{2} / \text { trap }\right)\end{array}$ & $\begin{array}{l}\text { Collection } \\
\text { date of first } \\
\text { WNV positive } \\
\text { mosquito pool }\end{array}$ & $\begin{array}{c}\text { Corvids } \\
\text { collected (n) }\end{array}$ & $\begin{array}{l}\text { Collection date } \\
\text { of first WNV } \\
\text { positive corvid }\end{array}$ & $\begin{array}{c}\text { Date of } \\
\text { symptom onset } \\
\text { of first WNND } \\
\text { case }\end{array}$ & $\begin{array}{l}\text { WNND cases } \\
\text { (n) }\end{array}$ \\
\hline 2009 & 92 & 119 & $21 \mathrm{Jul}$ & 1,005 & $30 \mathrm{Jul}$ & 19 Aug & 9 \\
\hline 2010 & 102 & 98 & 26 Aug & 806 & 1 Aug & $\mathrm{ND}^{\mathrm{c}}$ & 0 \\
\hline 2011 & 90 & 122 & $\mathrm{ND}^{\mathrm{c}}$ & 826 & $N^{c}{ }^{c}$ & $\mathrm{ND}^{\mathrm{c}}$ & 0 \\
\hline 2012 & 96 & 114 & $\mathrm{ND}^{\mathrm{c}}$ & 1,204 & $\mathrm{ND}^{\mathrm{c}}$ & $\mathrm{ND}^{\mathrm{c}}$ & 0 \\
\hline 2013 & 88 & 125 & $3 \mathrm{Jul}$ & 1,688 & $31 \mathrm{Jul}$ & 3 Aug & 20 \\
\hline
\end{tabular}

ND: none detected; WNND: West Nile neuroinvasive disease; WNV: West Nile virus.

${ }^{a}$ Mosquitoes are trapped from June to October every year.

b Birds are collected from May to October every year.

${ }^{c}$ ND indicates no finding of WNV evidence among mosquito pools or corvids tested, or no detection human cases of WNND.

for human cases. NAT screening is started in a week from the detection of the second positive mosquito pool or the positive bird. Following evidence produced by the environmental surveillance plan, in 2013 the NAT test was progressively introduced throughout seven (Bologna, Ferrara, Modena, Parma, Piacenza, Ravenna, Reggio Emilia) of the nine provinces in the EmiliaRomagna Region and stopped on 30 November.

\section{Laboratory analysis}

\section{Mosquito and bird samples}

Mosquito pools and bird samples were tested by a realtime polymerase chain reaction (RT-PCR), according to the method of Tang et al. [23]. Although this method is designed to detect WNV, other flaviviruses such as Usutu virus (USUV) can produce a positive signal if these are present in a sample at high concentration, therefore a traditional pan-flavivirus PCR, targeted to NS5 gene fragment, according to Scaramozzino et al. [24] and a traditional PCR protocol for WNV with the primers described in Lanciotti et al. [25], were applied on WNV positive samples to confirm results. Amplicons obtained were sequenced by an automated fluorescence-based technique following the manufacturer's instructions (ABI-PRISM 3130 Genetic Analyzer, Applied Biosystems, Foster City, CA). Traditional PCR designed for the detection of USUV, useful in differential diagnosis, was applied to the same samples. All confirmed WNV positive samples were sent to the

\section{TABLE 2}

Surveillance parameters obtained in the years of WNV activity, at the province level, Emilia-Romagna region, Italy, 2009-2013

\begin{tabular}{|c|c|c|c|c|c|c|c|c|c|}
\hline Year & Province & $\begin{array}{l}\text { Date of } \\
\text { initial } \\
\text { symptoms } \\
\text { in first } \\
\text { human case } \\
\text { of WNND }\end{array}$ & $\begin{array}{c}\text { Collection } \\
\text { date of } \\
\text { first WNV } \\
\text { positive } \\
\text { pool }\end{array}$ & $\begin{array}{c}\text { Number of } \\
\text { days that } \\
\text { mosquitos } \\
\text { anticipated } \\
\text { WNND }\end{array}$ & $\begin{array}{c}\text { VI max } \\
\text { (Culex } \\
\text { pipiens) }\end{array}$ & $\begin{array}{c}\text { Collection } \\
\text { date of } \\
\text { first WNV } \\
\text { positive } \\
\text { corvid }\end{array}$ & $\begin{array}{l}\text { Lag time } \\
\text { (in days) } \\
\text { between } \\
\text { finding } \\
\text { WNV in } \\
\text { mosquitoes } \\
\text { and birds }\end{array}$ & $\begin{array}{l}\text { WNND cases } \\
\text { (n) }\end{array}$ & $\begin{array}{c}\text { Incidence } \\
\text { WNND } \\
\text { (cases/ } \\
100,000)\end{array}$ \\
\hline 2010 & Bologna & - & - & $\mathrm{NC}^{\mathrm{a}}$ & 0.00 & 1 Aug & $\mathrm{NC}^{\mathrm{a}}$ & 0 & 0 \\
\hline 2010 & Modena & - & 23 Aug & $\mathrm{NC}^{\mathrm{a}}$ & 0.14 & 4 Aug & -19 & 0 & 0 \\
\hline 2013 & Modena & 3 Aug & $03 \mathrm{Jul}$ & 31 & 0.94 & $31 \mathrm{Jul}$ & 28 & 7 & 1.40 \\
\hline 2013 & Ferrara & 6 Aug & $17 \mathrm{Jul}$ & 20 & 0.87 & $31 \mathrm{Jul}$ & 14 & 5 & 1.12 \\
\hline 2013 & Bologna & 15 Aug & $17 \mathrm{Jul}$ & 29 & 0.63 & 3 Aug & 17 & 1 & 0.24 \\
\hline 2013 & Reggio E. & 16 Aug & $17 \mathrm{Jul}$ & 30 & 0.81 & 6 Aug & 20 & 6 & 1.43 \\
\hline 2013 & Parma & 11 Sep & $19 \mathrm{Jul}$ & 54 & 0.55 & 2 Sep & 45 & 1 & 0.34 \\
\hline 2013 & Ravenna & - & $24 \mathrm{Jul}$ & $\mathrm{NC}^{\mathrm{a}}$ & 0.27 & 30 Aug & 37 & 0 & 0 \\
\hline 2013 & Piacenza & - & 13 Aug & $\mathrm{NC}^{\mathrm{a}}$ & 0.37 & 8 Aug & -5 & 0 & 0 \\
\hline
\end{tabular}

NC: not calculated; VI: vector index; WNND: West Nile neuroinvasive disease; WNV: West Nile virus.

a Not calculated because no WNND cases were detected. 
National Reference Centre for Animal Exotic Diseases (CESME, Teramo) for confirmation, sequencing and determination of lineage.

\section{Human samples}

Blood donors: WNV screening was performed on single plasma samples by NAT and transcription mediated amplification (TMA) methods on fully automated system Tigris and Panther (Novartis). Repeatedly reactive samples were confirmed by RT-PCR on single sample on fully automated system Cobas 201 (Roche). Screening tests have been centralised to NAT Laboratory of the Blood Donors Biological Qualification Unit, AUSL of Bologna.

Patients with neuroinvasive disease: WNV RNA detection in human plasma, serum and cerebrospinal fluid samples (CSF) was performed by RT-PCR methods [26]. The presence of WNV-specific IgM and IgG antibodies in serum and cerebrospinal fluid (CSF) samples was tested by immunofluorescent antibody assay (IFA, Euroimmun) and further confirmed by microneutralisation assay (MNTA) [27].

\section{Cost evaluation}

As referred in the Introduction a cost evaluation analysis was conducted considering the two possible scenarios ( $A$ and $B$ ) during the five year period. Direct cost of each PCR performed on mosquito pools or birds was calculated at 15.00 EUR (personnel included). The cost of mosquito collection, species determination and pools preparation has been determined as a lump sum for the whole season.

We estimated an overall cost of 50.00 EUR per consignment of wild bird to the laboratory (each consignment consists on average of 3.5 birds; range: $1-22$ ). The laboratory diagnosis of a human case was calculated and found to have a mean cost of 74.00 EUR (personnel not included). The cost for a single NAT-test on a blood-donor's sample was 11.32 EUR in 2013, 12.10 EUR in 2012 while in the previous years it was 12.00 EUR. All costs per unit included value added tax (VAT).

\section{Statistical analysis}

Vector Index (VI) was calculated referring to the traps activated in the administrative border of each provinces (nomenclature of units for territorial statistics, NUTS3 level) by means of the formula $\mathrm{VI}=\Sigma \mathrm{N}_{\mathrm{i}} \mathrm{P}_{\mathrm{i}}$ (where $\mathrm{N}$ is the average number of $C X$. pipiens collected per trap/night and $\mathrm{P}$ is the Maximal Likelihood Estimation (MLE) of infection, estimated using the PooledInfRate 4.0 software [28]). As traps were activated mainly with fortnightly periodicity a series of $\mathrm{VI}$ values were obtained during the season; VImax is the maximum value the $\mathrm{VI}$ achieved during the season in a province.

Linear regression analysis was used to perform the correlation between $\mathrm{VI}$ and seasonal incidence of WNND human cases at the province level, using the $R$ Stats Package [29]. WNND cases incidence were transformed
FIGURE 2

Correlation between maximum vector index values (at province level in Culex pipiens) and the cases of West Nile neuroinvasive disease, Emilia-Romagna, Italy, 2009-2013

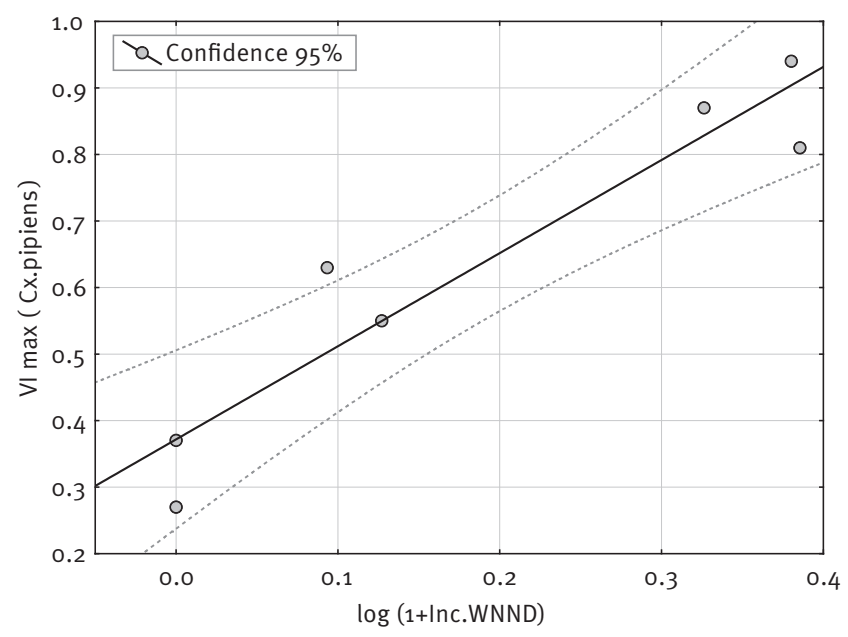

in $\log (1+$ cases incidence $)$ to normalise the data and control the variance.

\section{Results}

\section{Entomological and ornithological integrated} surveillance data

During the five year period, WNV activity was registered in the Emilia-Romagna region in 2009, 2010 and 2013, while no virus circulation was detected in 2011 and 2012. In the period between 2009 and 2010 WNV lineage 1 strain [30] was found, while in 2013 WNV lineage 2 was detected [31]. In 2009, mosquitoes were first in signalling the virus activity with five weeks anticipation to the first human case. In 2010 birds were first in signalling the virus circulation but no WNND cases were registered. In 2013 mosquitoes were first in signalling the virus circulation one month before the onset of the first WNND case (Table 1).

The 2010 and 2013 collected data allowed for a more precise analysis at the province level (Table 2). This was neither possible in 2009 nor in 2011 and 2012 because in 2009 the surveillance system was not sufficiently standardised, while in 2011 and 2012 no virus circulation was detected. In 2010, we did not register any WNND cases, but WNV circulation was detected during August in two provinces (Bologna and Modena) (Table 2). In 2013, in all five provinces where WNND cases occurred, both mosquitoes and birds signalled the virus circulation some weeks before the detection of human cases, in the range of 20 to 54 days for mosquitoes and slightly less anticipation for birds (3-12 days) (Table 2). 
TABLE 3

Confirmed West Nile neuroinvasive disease human cases, Emilia-Romagna, Italy, 2009-2013 ( $\mathrm{n}=29)$

\begin{tabular}{|l|c|c|c|c|c|}
\hline Year & $\begin{array}{c}\text { Surveillance } \\
\text { period }\end{array}$ & $\begin{array}{c}\text { Confirmed } \\
\text { WNND } \\
\text { cases } \\
(\mathrm{n})\end{array}$ & $\begin{array}{c}\text { Men } \\
(\mathrm{n})\end{array}$ & $\begin{array}{c}\text { Age } \\
\text { median in } \\
\text { years (range) }\end{array}$ & $\begin{array}{c}\text { Deaths } \\
(\mathrm{n})\end{array}$ \\
\hline 2009 & 15 Jun-31 Oct & 9 & 8 & $72(62-78)$ & 3 \\
\hline 2010 & 15 Jun-15 Nov & 0 & - & - & - \\
\hline 2011 & 15 Jun-15 Nov & 0 & - & - & - \\
\hline 2012 & 15 Jun-15 Nov & 0 & - & - & - \\
\hline 2013 & 15 Jun-30 Nov & 20 & 12 & $78(42-86)$ & 5 \\
\hline
\end{tabular}

WNND: West Nile neuroinvasive disease.

The correlation between VI values and WNND cases incidence at the province level was very high with $R^{2}=0.87$ $\left(\mathrm{F}_{1,5}=32.80\right.$ and $\left.\mathrm{p}<0.01\right)$ for $\mathrm{VI}$ mean (mean value during weeks 28-35) and with $R^{2}=0.90\left(F_{1,5}=43.53\right.$ and $\mathrm{p}$ <0.002) for VI max (peak seasonal value).

A positive correlation was also found between the date of collection of the first observed positive mosquito pool and the VI max (VI max values at province level correlate with the Julian day number of the first WNV positive pool with $R^{2}=0.74, F_{1,5}=13.88$ and $p<0.02$ ).

WNND cases were observed in provinces with VI max above 0.5 , while no human cases were registered in Ravenna and Piacenza provinces where the VI max resulted below 0.5 .

\section{Human cases}

In the Emilia-Romagna region human WNND cases were identified and reported in $2009[4,19]$ and 2013, while in 2010, 2011 and 2012 no cases were reported (Tables 1 and 3). In 2013 with the integrated surveillance system, the blood donor screening system identified 12 positive blood samples, of which four were detected before the first WNND human case in Emilia-Romagna.

\section{Cost analysis}

The analysis for cost evaluation was performed comparing two different scenarios: scenario $A$, implemented in Emilia-Romagna from 2009 to 2012, following the national surveillance guidelines; and scenario B, implemented in 2013, based on the results of the regional integrated surveillance system. In scenario A the only expenses are related to blood screening (Table 4). In scenario $B$, the cost evaluation analysis shows slight yearly variations in the entomological and ornithological surveillance related costs, with a larger yearly variation in blood screening related costs (Table 5). The economic comparison of the two scenarios shows that in some years scenario B would save the entire expense for blood screening (e.g. year 2011), in other cases, as year 2013, the integrated surveillance system, required higher costs, but enabled the identification of four positive donors, otherwise undetectable in the case of adopting scenario A. By considering the whole five year period the cumulative costs of environmental surveillance and guided blood screening resulted in costs of EUR 2,093,441, while the cumulative costs of blood screening without surveillance guidance resulted in costs of EUR 2,560,200.

\section{Discussion}

The WNV surveillance system developed in recent years in the Emilia-Romagna region demonstrated positive evidence in terms of sensitivity (capacity to detect WNV circulation even when at the enzootic level), early detection (capacity to detect the virus circulation well before the appearance of human WNND cases) and area specificity (capacity to indicate the spatial distribution of the risk for WNND human cases). In the 2010 season, WNV activity was detected in two provinces (Modena and Bologna) at very low level and no human cases were registered. A similar situation happened in the 2013 season in the provinces of Piacenza and Ravenna.

The integrated surveillance programme, which enabled to estimate virus circulation in the range of three to four weeks before the appearance of the first human WNND cases at the province level, may support a more

\section{TABLE 4}

Cost evaluations for scenario A - national plan for West Nile virus surveillance, Emilia-Romagna, Italy, 2009-2013

\begin{tabular}{|c|c|c|c|c|}
\hline \multirow[b]{2}{*}{ Year } & \multicolumn{3}{|c|}{ Blood screening surveillance } & \multirow[b]{2}{*}{$\begin{array}{c}\text { Overall } \\
\text { surveillance } \\
\text { cost }\end{array}$} \\
\hline & $\begin{array}{l}\text { Blood units } \\
\text { tested } \\
\text { (n) }\end{array}$ & $\begin{array}{l}\text { Positive } \\
\text { blood } \\
\text { units } \\
\text { detected } \\
\text { (n) }\end{array}$ & $\begin{array}{c}\text { Blood } \\
\text { screening } \\
\text { cost } \\
\text { (EUR) }\end{array}$ & \\
\hline $2009^{a}$ & 35,552 & 0 & 426,624 & 426,624 \\
\hline $2010^{a}$ & 66,689 & 0 & 800,268 & 800,268 \\
\hline $2011^{\mathrm{a}}$ & 60,258 & 0 & 723,096 & 723,096 \\
\hline $2012^{\mathrm{a}}$ & 0 & 0 & 0 & 0 \\
\hline $2013^{b}$ & 53,898 & 8 & 610,212 & 610,212 \\
\hline Total & 216,397 & 8 & $2,560,200$ & $2,560,200$ \\
\hline
\end{tabular}

In the national surveillance plan, screening of blood units is performed in a given year between 1 July and 30 November in all blood units of provinces where a human West Nile neuroinvasive disease (WNND) case or equine case of West Nile virus (WNV) infection has been registered in the previous year. For other provinces that year, blood unit screening is only initiated a week after an equine case of WNV infection or a human WNND case is detected in the current season.

a The national surveillance plan scenario was implemented in Emilia-Romagna during the year in question.

b In 2013, the Emilia-Romagna region adopted a surveillance system, which differed from the national surveillance plan. Costs that would have been generated by implementing the national surveillance plan have been estimated for the region, based on knowledge that no human WNND or equine WNV infection was detected in the whole region in the previous year, and knowledge of the time of occurrence of human WNND cases in given provinces of the region in 2013. 
TABLE 5

Cost evaluations for scenario B -regional integrated West Nile virus surveillance system, Emilia-Romagna, Italy, 2009-2013

\begin{tabular}{|c|c|c|c|c|c|c|c|c|c|}
\hline \multirow[b]{2}{*}{ Year } & \multicolumn{5}{|c|}{ Entomological and ornithological surveillance } & \multicolumn{3}{|c|}{ Blood screening surveillance } & \multirow[b]{2}{*}{$\begin{array}{l}\text { Overall } \\
\text { surveillance } \\
\text { cost }\end{array}$} \\
\hline & $\begin{array}{c}\text { Mosquito } \\
\text { collection } \\
\text { cost } \\
\text { (EUR) }\end{array}$ & $\begin{array}{l}\text { Mosquito } \\
\text { screening } \\
\text { cost }^{\times} \\
\text {(EUR) }\end{array}$ & $\begin{array}{c}\text { Bird } \\
\text { collection } \\
\text { cost }^{\mathrm{b}} \\
(\text { EUR) }\end{array}$ & $\begin{array}{c}\text { Bird } \\
\text { screening } \\
\text { cost }^{\mathrm{a}} \\
\text { (EUR) }\end{array}$ & $\begin{array}{l}\text { Total } \\
\text { (EUR) }\end{array}$ & $\begin{array}{l}\text { Blood units } \\
\text { tested } \\
\text { (n) }\end{array}$ & $\begin{array}{l}\text { Positive } \\
\text { blood units } \\
\text { detected } \\
\text { (n) }\end{array}$ & $\begin{array}{l}\text { Blood } \\
\text { screening } \\
\text { cost } \\
\text { (n) }\end{array}$ & \\
\hline $2009^{c, d}$ & 50,000 & 28,380 & 16,900 & 16,065 & 111,345 & 44,295 & 0 & 531,540 & 642,885 \\
\hline $2010^{c, d}$ & 50,000 & 34,770 & 11,550 & 12,180 & 108,500 & 11,679 & o & 140,148 & 248,648 \\
\hline $2011^{\mathrm{c}}$ & 50,000 & 23,325 & 14,650 & 12,810 & 100,785 & 0 & 0 & 0 & 100,785 \\
\hline $2012^{c}$ & 50,000 & 28,815 & 15,500 & 18,480 & 112,795 & 0 & 0 & 0 & 112,795 \\
\hline $2013^{\mathrm{e}}$ & 60,000 & 39,510 & 18,400 & 29,880 & 147,790 & 74,242 & 12 & 840,538 & 988,328 \\
\hline Total & 260,000 & 154,800 & 77,000 & 89,415 & 581,215 & 130,216 & 12 & $1,512,226$ & $2,093,441$ \\
\hline
\end{tabular}

WNV: West Nile virus.

Entomological and ornithological surveillance has been conducted during the whole study period in the Emilia-Romagna region, however the results of this surveillance were not effectively taken into account for blood screening surveillance until 2013 . Before 2013 the national WNV surveillance plan was in place in the region, whereby some particular rules for screening blood units were applied. In 2013 , an integrated regional WNV surveillance system was implemented in Emilia-Romagna, which requires that WNV nucleic acid testing screening is applied to all blood donors in a province after reports of at least two positive mosquito pools or one positive bird by the entomological or ornithological surveillance network, within the limits of the province. NAT screening is started a week after the detection of the second positive mosquito pool or positive bird.

Including for each positive sample, the cost of three polymerase chain reactions and the cell culture and sequencing.

a Free because voluntary birds consignments.

In this year, blood screening surveillance in Emilia-Romagna does not follow the integrated regional WNV surveillance system, but the national WNV surveillance plan. However, based on entomological surveillance results, it is possible to predict how many blood units would have been screened should the regional surveillance system have been followed, and derive the costs accordingly.

d In this year, the blood units that would have been screened by the integrated WNV regional surveillance system happened to have been screened according to the national surveillance plan, so the number of positive blood units that would have been detected via the integrated WNV regional surveillance system is known.

e Integrated regional surveillance system implemented in Emilia-Romagna.

evidence-based policy of blood screening, thus avoiding blood units' analyses in case of virus absence, even in areas which were affected in the previous year. As the WNV epidemiology is largely unpredictable by modelling, an integrated surveillance is required to support the risk assessment.

Once validated during a sufficient number of seasons the entomological and ornithological surveillance may be considered as a valid tool to guide the blood and organ donations safety policy, to organise a more evidence-based information to citizens, in order to enhance the adoption of personal protection measures and precautionary behaviour, and eventually to operate adult vector control in sites at high risk (e.g. nocturnal public events in vegetated areas) [32].

The comparative analysis between the two possible scenarios (with and without the environmental surveillance) shows that the integrated surveillance system may have a better performance in terms of costs and public health benefits. In the case of Emilia-Romagna region the cost comparison of the two approaches showed that the surveillance could have allowed the saving of at least EUR 0.5 million in the period from 2009 to 2013 (Table 4 and 5). Differences in costs between the two scenarios may of course be subject to variability depending on the epidemiological circumstances in the long term. Furthermore, during the
2013 season, which came following a year of no WNV detection in the Emilia-Romagna region, the surveillance system assisted the prompt starting of the blood screening before the appearance of any human case, allowing the detection of four WNV positive blood units, which would not have been detected in case of the application of the national plan procedure (as the national plan requires the blood screening in provinces where human cases were reported in the previous year or following the detection of a human case in the current year). So the environmental surveillance may be helpful in to detect WNV circulation in an area in a year which follows an absence of human or equine cases in the previous season, as it may advise about possible risk of infection via transfusion well before the detection of human cases.

The surveillance system, as it has been developed in the Emilia-Romagna region, allowed to detect and monitor the WNV affected areas where preventive sanitary measures may be conveniently adopted. The province level seems the most appropriate administrative NUTS where the implementation of laboratory screening methods, such as NAT screening of blood units, can be conveniently managed.

An extra value of the environmental surveillance is the possibility to detect the circulation of other arboviruses vectored by mosquitoes and other haematophagous 
insects readily collected by the $\mathrm{CO}_{2}$ baited traps, such as sand flies, culicoides and black flies, as well. We therefore propose to adopt the WNV environmental surveillance as part of the public health policy in the region.

\section{Acknowledgements}

We thank all the technicians that during the five years performed the field and the laboratory work, the Province Agricultural Bureaux which supported the birds collections, the regional group for the surveillance of vector borne diseases which actively supported the work organisation. This work was financed by the Emilia- Romagna Public Health Department.

\section{Conflict of interest}

None declared.

\section{Authors' contributions}

Romeo Bellini prepared the first draft of the manuscript; Alessandro Albieri, Paola Angelini, Romeo Bellini, Emanuela Bedeschi, Paolo Bonilauri, Mattia Calzolari, Michele Dottori, Alba Carola Finarelli, Silvano Natalini, Marco Tamba contributed to the environmental surveillance planning and management; Mattia Calzolari and Paolo Bonilauri provided the laboratory results for birds and mosquitoes virological screening; Giada Rossini, Paolo Gaibani, Caterina Vocale, Maria Paola Landini provided the laboratory results for human cases; Claudio Velati, Nadia Pascarelli provided the haemovigilance costs and data on surveillance in the blood donor population; Roberto Cagarelli, Marco Carrieri, Andrea Mattivi, Marco Tamba conducted the data analysis; all authors critically read the manuscript and approved the final submitted version.

\section{References}

1. Reiter P. West Nile virus in Europe: understanding the present to gauge the future. Euro Surveill. 2010;15(10):19508. PMID:20403311

2. Hubálek Z. European experience with the West Nile virus ecology and epidemiology: could it be relevant for the New World? Viral Immunol. 2000;13(4):415-26. http://dx.doi. org/10.1089/vim.2000.13.415 PMID:11192288

3. Kramer LD, Styer LM, Ebel GD. A global perspective on the epidemiology of West Nile virus. Annu Rev Entomol. 2008;53(1):61-81. http://dx.doi.org/10.1146/annurev. ento.53.103106.093258 PMID: 17645411

4. Tsai TF, Popovici F, Cernescu C, Campbell GL, Nedelcu NI. West Nile encephalitis epidemic in southeastern Romania. Lancet. 1998;352(9130):767-71. http://dx.doi.org/10.1016/S01406736(98)03538-7 PMID:9737281

5. Calzolari M, Bonilauri P, Bellini R, Albieri A, Defilippo F, Maiol $G$, et al. Evidence of simultaneous circulation of West Nile and Usutu viruses in mosquitoes sampled in Emilia-Romagna region (Italy) in 2009. PLOS ONE. 2010;5(12):e14324. http:// dx.doi.org/10.1371/journal.pone.0014324 PMID:21179462

6. Chaskopoulou A, Dovas Cl, Chaintoutis SC, Kashefi J, Koehler P, Papanastassopoulou M. Detection and early warning of West Nile Virus circulation in Central Macedonia, Greece, using sentinel chickens and mosquitoes. Vector Borne Zoonotic Dis. 2013;13(10):723-32. http://dx.doi.org/10.1089/vbz.2012.1176 PMID:23919609

7. Mouchet J, Rageau J, Laumond C, Hannoun C, Beytout D, Oudar J, et al. Epidémiologie du virus West Nile: étude d’un foyer en Camargue. V. Le vecteur: Culex modestus Ficalbi Diptera; Culicidae. [Epidemiology of West Nile virus: study of a focus in Camargue. V. The vector: Culex modestus Ficalbi Diptera;
Culicidae]. Ann Inst Pasteur (Paris). 1970;118(6):839-55. French. PMID:5464130

8. Anderson JF, Main AJ. Importance of vertical and horizontal transmission of West Nile virus by Culex pipiens in the Northeastern United States. J Infect Dis. 2006;194(11):1577-9. http://dx.doi.org/10.1086/508754 PMID:17083043

9. Andreadis TG, Armstrong PM, Bajwa WI. Studies on hibernating populations of Culex pipiens from a West Nile virus endemic focus in New York City: parity rates and isolation of West Nile virus. J Am Mosq Control Assoc. 2010;26(3):257-64. http:// dx.doi.org/10.2987/10-6004.1 PMID:21033052

10. Reisen WK, Fang Y, Lothrop HD, Martinez VM, Wilson J, Oconnor P, et al. Overwintering of West Nile virus in southern California. J Med Entomol. 2006;43(2):344-55. http://dx.doi. org/10.1603/0022-2585(2006)043[0344:00WNVI]2.0.CO;2 PMID:16619621

11. Calzolari M, Bonilauri P, Bellini R, Albieri A, Defilippo F, Tamba M, et al. Usutu virus persistence and West Nile virus inactivity in the Emilia-Romagna region (Italy) in 2011. PLoS ONE. 2013;8(5):e63978. http://dx.doi.org/10.1371/journal. pone.0063978 PMID:23667694

12. Danis K, Papa A, Theocharopoulos G, Dougas G, Athanasiou M, Detsis $M$, et al. Outbreak of West Nile virus infection in Greece, 2010. Emerg Infect Dis. 2011;17(10):1868-72. http://dx.doi. org/10.3201/eid1710.110525 PMID:22000357

13. European Centre for Disease Prevention and Control (ECDC). Reported cases of West Nile fever for the EU and neighbouring countries. Transmission season 2013 and previous transmission seasons; latest update: 22/08/2014. Stockholm: ECDC; Aug 2014. Available from: http://www.ecdc.europa.eu/ en/healthtopics/west_nile_fever/West-Nile-fever-maps/Pages/ historical-data.aspx</unknown

14. Zeller H, Lenglet A, Van Bortel W. West Nile virus: the need to strengthen preparedness in Europe. Euro Surveill. 2010;15(34):19647. PMID:20807490

15. Semenza JC, Zeller H. Integrated surveillance for prevention and control of emerging vector-borne diseases in Europe. Euro Surveill. 2014;19(13):20757. http://dx.doi.org/10.2807/15607917.ES2014.19.13.20757 PMID:24721535

16. Kwan JL, Park BK, Carpenter TE, Ngo V, Civen R, Reisen WK. Comparison of enzootic risk measures for predicting West Nile disease, Los Angeles, California, USA, 2004-2010. Emerg Infect Dis. 2012;18(8):1298-306. http://dx.doi.org/10.3201/ eid1808.111558 PMID:22840314

17. Centers for Disease Control and Prevention (CDC). Epidemic/ epizootic West Nile Virus in the United States: guidelines for surveillance, prevention, and control. 3rd Revision. Fort Collins: U.S. Department of Health and Human Services, Public Health Service, National Center for Infectious Diseases, Division of Vector-Borne Infectious Diseases; 2003.

18. Brown EG. California mosquito-borne virus surveillance \& response plan. California: California Department of Public Health Mosquito \& Vector Control Association of California University of California; 2012.

19. Carney RM, Ahearn SC, McConchie A, Glasner C, Jean C, Barker C, et al. Early warning system for West Nile virus risk areas, California, USA. Emerg Infect Dis. 2011;17(8):1445-54 10.3201/ eid1708.100411 PMID:21801622

20. Angelini P, Tamba M, Finarelli AC, Bellini R, Albieri A, Bonilauri $P$, et al. West Nile virus circulation in Emilia-Romagna, Italy: the integrated surveillance system 2009. Euro Surveill. 2010;15(16):19547. PMID:20430000

21. Calzolari M, Gaibani P, Bellini R, Defilippo F, Pierro A, Albieri A, et al. Mosquito, bird and human surveillance of West Nile and Usutu viruses in Emilia-Romagna Region (Italy) in 2010. PLoS ONE. 2012;7(5):e38058. http://dx.doi.org/10.1371/journal. pone.0038058 PMID:22666446

22. Rossini G, Cavrini F, Pierro A, Macini P, Finarelli A, Po C, et al. First human case of West Nile virus neuroinvasive infection in Italy, September 2008 - case report. Euro Surveill. 2008;13(41):19002. PMID:18926106

23. Tang Y, Anne Hapip C, Liu B, Fang CT. Highly sensitive TaqMan RT-PCR assay for detection and quantification of both lineages of West Nile virus RNA. J Clin Virol. 2006;36(3):177-82. http:// dx.doi.org/10.1016/j.jcv.2006.02.008 PMID:16675298

24. Scaramozzino N, Crance JM, Jouan A, DeBriel DA, Stoll F, Garin D. Comparison of flavivirus universal primer pairs and development of a rapid, highly sensitive heminested reverse transcription-PCR assay for detection of flaviviruses targeted to a conserved region of the NS5 gene sequences. Clin Microbiol. 2001;39(5):1922-7. http://dx.doi.org/10.1128/ JCM.39-5.1922-1927.2001 PMID:11326014

25. Lanciotti RS, Kerst AJ, Nasci RS, Godsey MS, Mitchell CJ, Savage HM, et al. Rapid detection of west nile virus from human clinical specimens, field-collected mosquitoes, and 
avian samples by a TaqMan reverse transcriptase-PCR assay. J Clin Microbiol. 2000;38(11):4066-71. PMID:11060069

26. Linke S, Ellerbrok H, Niedrig M, Nitsche A, Pauli G. Detection of West Nile virus lineages 1 and 2 by real-time PCR. I Virol Methods. 2007;146(1-2):355-8. http://dx.doi.org/10.1016/j. jviromet.2007.05.021 PMID:17604132

27. Rossini G, Carletti F, Bordi L, Cavrini F, Gaibani P, Landini MP, et al. Phylogenetic analysis of West Nile virus isolates, Italy, 2008-2009. Emerg Infect Dis. 2011;17(5):903-6. http://dx.doi. org/10.3201/eid1705.101569 PMID:21529408

28. Biggerstaff BJ. PooledInfRate, Version 4.0: a Microsoft Office Excel Add-In to compute prevalence estimates from pooled samples. Atlanta: Center for Disease Control and Prevention; 2009.

29. R Development Core Team. R: A Language and Environment for Statistical Computing. Vienna: R Foundation for Statistical Computing; 2012., ISBN 3-900051-00-3.Available from: http: // www.R-project.org/

30. Monaco F, Savini G, Calistri P, Polci A, Pinoni C, Bruno R, et al. 2009 West Nile disease epidemic in Italy: first evidence of overwintering in Western Europe? Res Vet Sci. 2011;91(2):3216. http://dx.doi.org/10.1016/j.rvsc.2011.01.008 PMID:21334703

31. Calzolari M, Monaco F, Montarsi F, Bonilauri P, Ravagnan S, Bellini R, et al. New incursions of West Nile virus lineage 2 in Italy in 2013: the value of the entomological surveillance as early warning system. Vet Ital. 2013;49(3):315-9. PMID:24002939

32. Bellini R, Zeller H, Van Bortel W. A review of the vector management methods to prevent and control outbreaks of West Nile virus infection and the challenge for Europe. Parasites and Vectors. 2014;7(1):323. http://dx.doi. org/10.1186/1756-3305-7-323 PMID:25015004 